\title{
上向き雷撃路を考慮した鉄塔縮小モデルのサージ特性
}

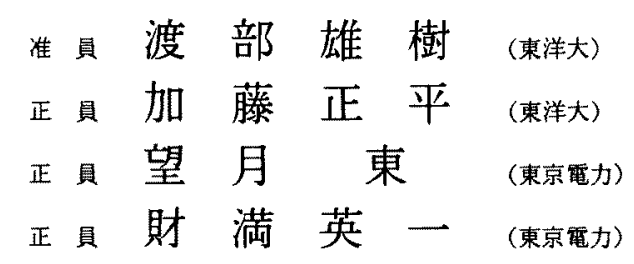

\section{Surge Characteristics of A Miniature Transmission Tower Model Simulated Upward Lightning Current Path}

\author{
Yuuki Watanabe, Associate, Shohei Kato, Member (Toyo University) \\ Azuma Mochizuki, Member, Eichi Zaima, Member (Tokyo Electric Power Co.,)
}

\begin{abstract}
It is investigated surge characteristics of a miniature transmission tower model with power lines and overhead ground wires experimentally. The Lightning path from the tower to sky is simulated by a current delay line of which the velocity is a several tenth of the light velocity. Experimental results show that the surge voltage in the tower is not very much affected by the upward current velocity, and the voltage between the tower arm and the power line decreases from the upper line to the lower one.

We obtained a higher surge impedance of the tower without overhead ground wires than that of the one with wires. The transient mutual coupling factor between the overhead ground wires and power lines estimated from the results shows small values, about a fourth of the conventional values that is used in an analysis of a slow front wave surge.
\end{abstract}

キーワート : 鉄塔サージ、鉄塔雷撃、サージインピーダンス、結合率

\section{1. まえがき}

最近のサージ解析は EMTP 等の回路シミュレータを使 用することにより高い精度が得られるようになってきた。 回路シミュレータでは等価回路桡成や回路定数の選定によ って結果が変化する場合があり、鉄塔を含む線路の等価回 路が多数提案されている。また、鉄塔のサージインピーダ ンスを求める式も多数提案されている。しかし、これらの モテルを使用した解析結果と実鉄塔の様々な条件下での実 測結果とは差を生じる場合もあり、実鉄塔や鉄塔モデルを 使用した実測結果を利用したモテル(1) (4) も多い。鉄塔 はその送電線路構成上、様々な構造形態をもち、サージイ ンピーダンスが鉄塔搆造に依存するため、鉄塔を含む線路 のサージ解析を複雑にしている。実鉄塔での測定は大規模 となるため、また雷サージ特性は印加波や観測する時間頖 域を小さくすることでサイズを縮小できることから鉄塔縮 小モデルによる測定 ${ }^{(5) \sim(7)} も$ 行なわれている。

サージインピーダンスの測定には様々な方法や測定条件 があるが条件や測定方法により值が異なり、測定方法間で 測定值の換算が必要となる。雷撃の電流路に該当する電流
印加線と鉄塔との角度による鉄塔サージインピーダンスの 変化を調べた結果 ${ }^{(8)}$ では、印加線を水平としたときより も、垂直としたときの方がインピーダンスは大きくなる。 一般に、鉄塔のサージ特性の測定では、水平な電流印加線 で鉄塔塔頂へ印加されることが多いが、実際の雷慗では大 地に垂直な雷慗路となることが多いので、垂直方向に模擬 することが望ましい。

鉄塔内の電流速度は光速あるいは光速の数 $10 \% の$ 速度 として解析されている。一方、帰還雷撃路の電流速度はこ れまで光速とした測定や解析が行われてきた。最近、小島 らは逆フラッシオーバ解析で雷撃路からの影禘を考虑する

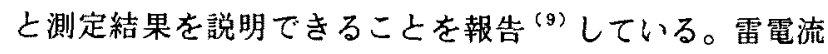
の速度が低下すると線路と雷撃路の電磁結合が異なり鉄塔 のサージ特性に影贸を生じる可能性が考えられる。

そこで鉄塔樎小モテルにおいて実雷繋での電流速度を考 慮した膟還雷撃電流路モデルを使用して鉄塔のサージイン ピーダンスに与える影響を調へた。

\section{2. 雷慗電流速度依存特性の测定}


〈2・1〉测定眍置测定配犆を図 1 に示す。鉄塔は送 電線路を実装した状熊で測定する。高さ $1.8 \mathrm{~m}$ の鉄塔縮小 モデルを用い、長さ $5.2 \mathrm{~m}$ の架空地線 2 条と電力線 6 条の 線路中央に鉄塔モテルを配置し、それぞれ鉄塔塔頂、鉄塔 アーム下に水平に畋架した。架空地線は直径 $6 \mathrm{~mm}$ の冈柱 導体線を架架地線アーム先端に接続し、各架架地線終端は 抵抗 $510 \Omega$ を莗直にアース板に接地している。電力線 には直径 $4 \mathrm{~mm}$ の円柱導体線を使用し、終端は架空地線と 同様に垂直にアース板に接地した。雷撃印加点は鉄塔塔頂 部の片例架架地線アーム先端とし、雷整電流路は鉄塔塔頂 の印加点より垂面に懸架して㷌還雷揧電流路の上空への主 放電を模擬する。塔頂に電流源を配置する代わりに直角波 電圧源を地上に䈯き、そこから同軸ケーブルで塔頂まで引 き込み出力抵抗 ${ }^{(10)}$ 的 $200 \Omega$ を経て電流を鉄塔と雷撃電流 路へ印加する。同軸ケーブルシースはアース電位に固定す るようにアース板、鉄塔に接触固定する。

電流の測定は電流プローブにより印加電流、架空地線電 流を测定する。また、各鉄塔電位の測定は FET 䉓死プロ ーブを収めた铜パイプ製の電生測定接地線(い)を鉄塔近傍 まで延ばし鉄塔塔頂電压、アーム電压、電力線電圧を測定 する。

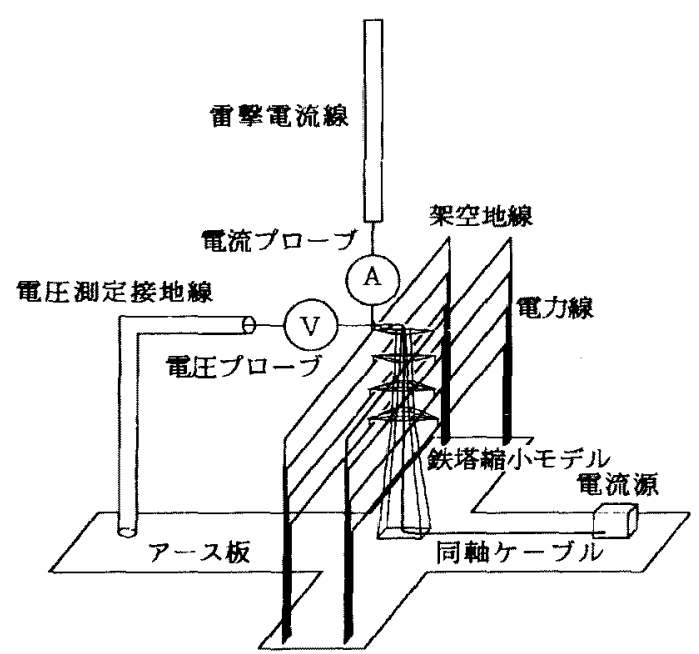

図 1 実騃配置図

Fig.1. Experimental layout

〈2・2〉サージインピーダンスの算出法 鉄塔のサー シインピーダンスは測定した電流波形・電压波形より同一 経過時間における波高值を求め、その值をもとに算出する 手法をとる。㷌還雷撃により塔頂の電荷は開放され鉄塔本 体や架空地線に分流する。これを模擬するためには鉄塔塔 頂への電流源の配置が理想的とされるが電源サイズの都合 上、塔頂への配置は困難であるため電流は印加線により印 加点に供給する。これにより印加電流の分流は図 2 の等価 回路構成となる。

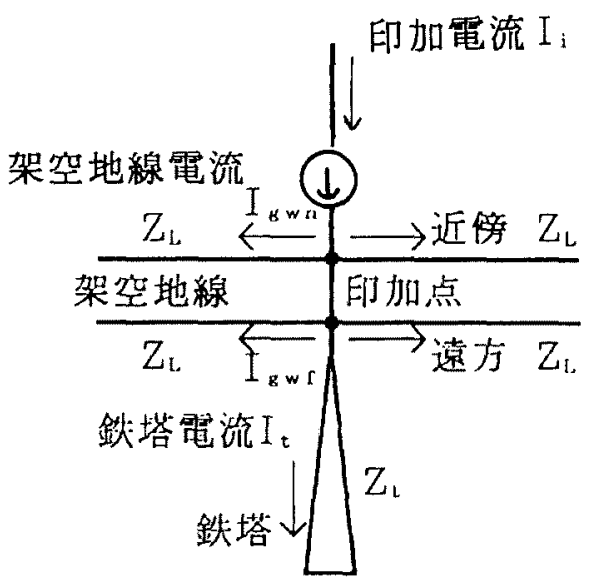

図 2 等価回路

Fig.2. Equivalent circuit of the measuring system

印加電流は印加点から架空地線電流と鉄塔電流に分流す るため印加電流と架空地線電流の差を求め鉄塔電流とする。

$$
I_{t}=I_{i}-2 \cdot\left(I_{g w n}+I_{g w p}\right)
$$

ここで、I $\mathrm{i}$ : 鉄塔電流、I $\mathrm{i}:$ :印加電流、

$I_{g w n}:$ 近傍側架空地線電流、 $I_{g w f}:$ 遠方侧架空地線

電流

図 2 等価回路で測定した塔頂電圧と鉄塔電流の比から 鉄塔サージインピーダンスを計算する。

$$
Z_{t}=V I I_{t}
$$

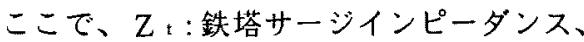

$$
\mathrm{V} \text { : 塔頂電压 }
$$

架空地線のサージインピーダンスは次式で求める。

$$
Z_{\text {gwl }}=V / I_{\text {gwi }}
$$

ただし、添字 gwi は近傍、遠方側を表す。

〈2・3〉雷耧電流線雷撃電流速度によって鉄塔のサ 一ジ特性が変化するか調べために次の伝搬速度の異なる 3 種類の雷撃電流路を使用した。

（1）長さ $1.81 \mathrm{~m}$ 、直径 $6 \mathrm{~mm}$ の銅パイプ製直線円柱導体線 を光速伝搬模擬用に使用する直線導体モテル

(2) 長さ約 $1.8 \mathrm{~m}$ 、直径 $8.4 \mathrm{~mm}$ のアクリル丸棒の軸方向に 導線を折り返しに巻いて固定し直線導体モデルの約四倍の 導体全長 $(7.2 \mathrm{~m})$ を持たせた折返し巻線モデ

(3) 長さ䄪 $1.8 \mathrm{~m}$ 、直径 $8.4 \mathrm{~mm}$ のアクリル丸棒に䄪 $13.3 \mathrm{~m}$ の導線をコイル状に光速の伝搬速度の $1 / 3$ となるような巻 線ピッ子 $(3.6 \mathrm{~mm}) て ゙$ 巻かれたコイル巻線モデル

いずれも図1に示すように垂直に馝架して上端を開放端 とする。図 3 に雷撃電流路モデルの略図を示す。 

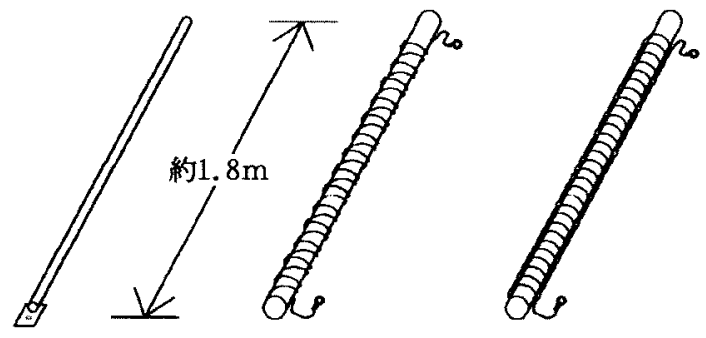

（a）直線導体線

(b) 折返し巻線

(c) コイル巻線

図 3 雷慗電流路モテル

Fig.3. Models of lightning current line

$\langle 2 \cdot 4\rangle$ 测定結果圀 4 に直線導体モテルの各测定波 形を示す。直角波電圧源からの信号䄪 $30 \mathrm{~V}$ を $50 \Omega$ の特性 インピーダンスを有する同軸ケーブルで鉄塔塔頂に引き込 み、出力抵抗が $200 \Omega$ である直角波電流源とした。印加点 直前に波形整形回路を設け、立ち上がり時にピークを示す 印加電流を直角波に近つけている。直線導体の場合、印加 電流波形の立ち上がり後から方形波平坦部を経て立ち下が

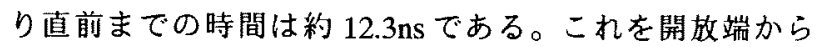
の反射波の到達時間と考え雷撃電流速度に換算すれば光速 の䄪 $98 \%$ となり、ほぼ光速を模擬していると言える。

架空地線電流は印加点近傍側と遠方側とで波形が異なる。 印加点近傍側電流は印加点に近いことから立ち上がり時に 図 4 (c)のようなスパイク電流が流れその後もやや振動す る。一方、遠方側䉓流波形は直角波電流とスパイク状電流 の差の電流が流れるため緩やかに立ち上がる。電流波高值 も近傍側と遠方側では明らかに近傍側のほうが多く流れて いる。

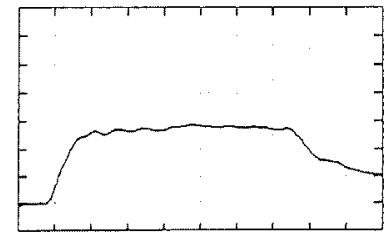

$10 \mathrm{~mA} / \mathrm{div} 2 \mathrm{~ns} / \mathrm{div}$

(a) 印加電流

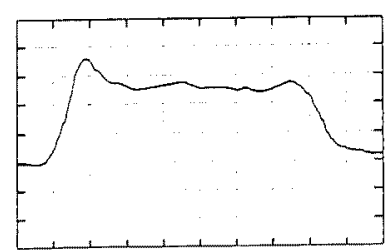

$2 \mathrm{~mA} / \mathrm{div} 2 \mathrm{~ns} / \mathrm{div}$

(c) 近傍側架空地楾電流

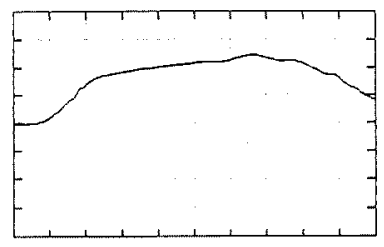

$1 \mathrm{~V} / \mathrm{djv} \quad 2 \mathrm{~ns} / \mathrm{div}$

(b) 塔頂電圧

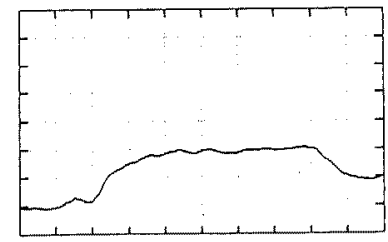

$2 \mathrm{~mA} / \mathrm{div} 2 \mathrm{~ns} / \mathrm{div}$

(d) 遠方側架空地楾電流

図 4 直線導体モデルの測定波形

Fig.4. Measured waveforms of straight conductor model
図 4 の測定波形より鉄塔電流を印加電流亡架空地線電流 の総和の差から求める。塔頂電压が立ち上がりから最大波 高值になるまでの時刻 11.4nsにおける電流値を使用して インピーダンスを求める。この時刻における印加電流 I； は $29 \mathrm{~mA}$ であり、近傍側架空地線電流 I $\mathrm{g}$ w $\mathrm{n}$ は約 $4.8 \mathrm{~mA}$ 、 遠方側架空地線電流 I g w $\mathrm{f}$ は約 $3.9 \mathrm{~mA}$ である。これより全 架架地線電流は的 $17.4 \mathrm{~mA}$ となり、(1) 式より鉄塔電流 1 、 は約 $11.6 \mathrm{~mA}$ と計算される。

図 4 (b)における塔頂電圧值は約 $2.4 \mathrm{~V}$ である。これと 鉄塔電流值との比から鉄塔のサージインピーダンスを求め れば、(2) 式より鉄塔サージインピーダンスZ、は 207V/A となる。また、(3)式より架空地線サージインピーダンス $Z_{\mathrm{L}}$ は近傍側で 521V/A、遠方側で 615V/A である。

図 5 に折返し巻線モデルの測定波形を示す。直角波電死 約 $30 \mathrm{~V}$ を出力抵抗 $200 \Omega$ で電流源として印加している。 このモテルでは線路の長さから考えて光速の約 $1 / 4$ の伝搬 速度を期待した。しかし開放端反射波到達時間は的 $23.5 \mathrm{~ns}$ であり、伝搬速度は光速の的 $51 \%$ にな。これは線路が 分布定数線路となり巻線間の静電容量によって導体を流れ る導伝電流よりも早く架間を伝搬する電磁波による電流が あるためであろう。図 3 (b) の他に導体長を変えたモテル を試みたが伝搬速度は光速の半分程度しかならなかった。 折返し巻線はコイル巻線モデルの遅延構造と異なり、折返 しに電流が流れるために軸方向に発生する磁束はより小さ くなる。

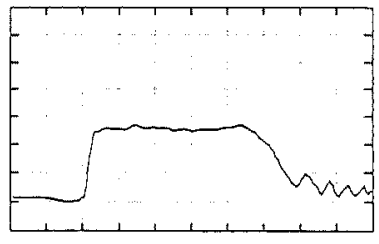

$10 \mathrm{~mA} / \mathrm{div} \quad 5 \mathrm{~ns} / \mathrm{div}$

(a) 印加電流

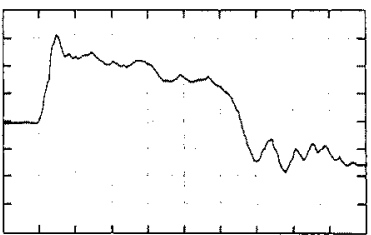

$2 \mathrm{~mA} / \mathrm{div} \quad 5 \mathrm{~ns} / \mathrm{div}$

(c) 近傍側架空地線電流

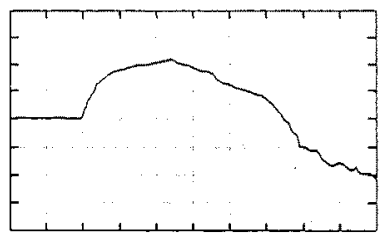

$1 \mathrm{~V} / \mathrm{div} \quad 5 \mathrm{~ns} / \mathrm{div}$

(b) 塔頂電圧

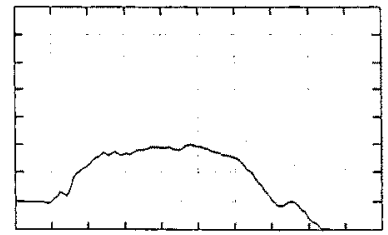

$2 \mathrm{~mA} / \mathrm{div} \quad 5 \mathrm{~ns} / \mathrm{div}$

(d) 遠方側架空地線電流
Fig.5. Measured waveforms of zigzag conductor model

塔頂電圧の最大波高となる時刻は $12 \mathrm{~ns}$ であり、この時

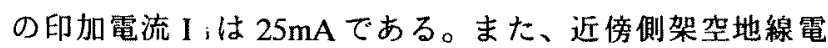
流 I $\mathrm{g}$ w である。これにより (1) 式から鉄塔電流 I は約 $10.2 \mathrm{~mA} て ゙$ ある。

図 5 (b) で塔頂電圧は䄪 $2.1 \mathrm{~V}$ である。(2) 式より鉄塔の 
サージインピーダンスを求めるとZ、は 206V/A、(3) 式よ

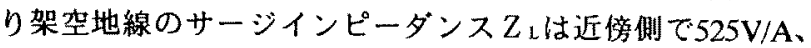
遠方侧で 618V/A である。

図6にコイル巻線モデルの各測定波形を示す。印加電流 の開放端反射波到達時間は的 42ns であり光速の約 $29 \%$ に 相当する。寒雷撃模擬を目的亡した光速の 1/3に近い伀搬 速度になっている。電流波形整形のため出力抵抗を $300 \Omega$ に贸更した。このため、電流波形は波頭部の微小な振動以 外は方形波に近いものになった。

架空地線の笔流波形は直線導体モテルよりも大きく振動 する。波形の特徴は印加点近傍侧 - 遠方側とも直線導体モ テルと同様である。すなわち、電流の波高值は近傍側と遠 方側では近傍側のほうが多く流れ、また立ち上がり時に最 も多く流れている。

図 6 (b) の塔頂電圧波形の立ち上がりから最大波高值ま での時刻 12nsにおりる印加電流 I は $17 \mathrm{~mA}$ である。また、 近傍側架空地線電流 $\mathrm{Ig}$ w $\mathrm{n}$ は䄪 $2.45 \mathrm{~mA}$ 、遠方側架空地線 電流 I gw は䄪 $2.4 \mathrm{~mA}$ である。これにより(1) 式から鉄塔 電流 I、は約 $7.3 \mathrm{~mA}$ と計算される。

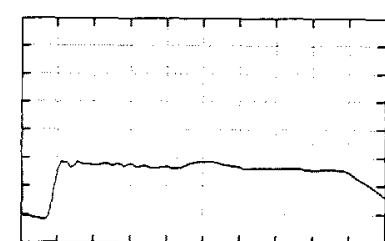

$10 \mathrm{~mA} / \mathrm{div} \quad 5 \mathrm{~ns} / \mathrm{div}$

(a) 印加電流

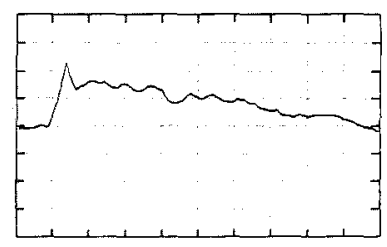

$2 \mathrm{~mA} / \mathrm{div} 5 \mathrm{~ns} / \mathrm{div}$

(c) 近傍側架空地線電流

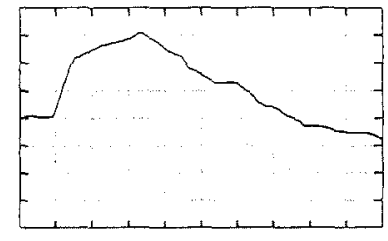

$500 \mathrm{mV} / \mathrm{div} \quad 5 \mathrm{~ns} / \mathrm{div}$

(b) 塔頂電压

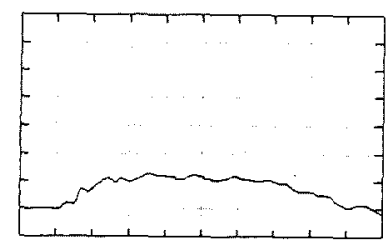

$2 \mathrm{~mA} / \mathrm{div} \quad 5 \mathrm{~ns} / \mathrm{div}$

(d) 遠方側架空地線電流

目 6 コイル巻線モテルの測定波形

Fig.6. Measured waveforms of winding conductor mode]
各サージインピーダンスは図 6 (b) の塔頂䇩王值が䄪

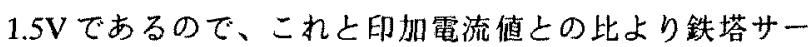
シインピーダンス Z、は 205V/A、架空地線サージインピ ーダンス $Z_{\mathrm{L}}$ は近傍側で 612V/A、遠方側で625V/Aとなる。 各雷撃モテルにおける鉄塔各部のサージインピーダンス を表 1 に示す。表には図 2 で架空地線を除いた鉄塔単体の 場合におりる測定結果屯同様に示し架空地線の勃果を調へ

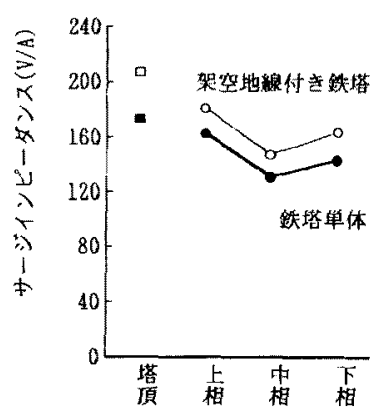

(a) 直楾導体モデル

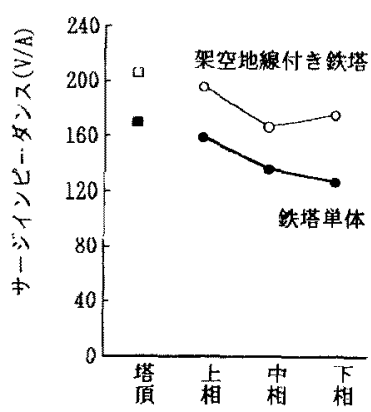

(b) 折返し巻線モデル

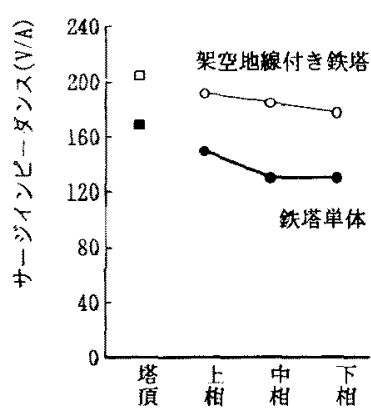

(c) コイル卷線モテル

図 7 鉄塔各部の電位分布

Fig.7. Voltage distribution of tower arms

表 1 雷撃モデルのサージインピーダンス測定結果

Table 1. Surge impedance of each model

\begin{tabular}{|c|c|c|c|c|c|c|c|}
\hline \multirow{2}{*}{\multicolumn{2}{|c|}{ 雷撃電流路モテル }} & \multicolumn{2}{|c|}{ 直線導体モデル } & \multicolumn{2}{|c|}{ 折返し巻線モデル } & \multicolumn{2}{|c|}{ コイル巻線モデル } \\
\hline & & & 鉄塔単体 & & 鉄塔單体 & & 鉄塔単体 \\
\hline \multicolumn{2}{|c|}{ 光速に対する割合（\%) } & 98 & 96 & 51 & 50 & 29 & 29 \\
\hline \multirow{5}{*}{$\begin{array}{r}\text { サージインピーダンス } \\
(V / A)\end{array}$} & 鉄塔塔頂 & 207 & 173 & 206 & 170 & 205 & 169 \\
\hline & 上相アーム & 181 & 163 & 196 & 159 & 192 & 150 \\
\hline & 中相アーム & 147 & 131 & 167 & 136 & 185 & 131 \\
\hline & 下相アーム & 164 & 143 & 176 & 127 & 178 & 131 \\
\hline & $\begin{array}{l}\text { 近傍架空地線 } \\
\text { 㟟方架空地線 }\end{array}$ & $\begin{array}{l}521 \\
615\end{array}$ & & $\begin{array}{l}525 \\
618\end{array}$ & & $\begin{array}{l}612 \\
625 \\
\end{array}$ & \\
\hline
\end{tabular}


た。鉄塔各部のサージインピーダンスは各相のアーム先端 で測定した電圧波形の最大值と鉄塔電流值の比より求めた。 この結果から各雷撃モデルにおける鉄塔各部の電位分布を 図 7 に示す。

鉄塔塔頂のサージインピーダンスは各雷撃電流路モテル とも206 $\Omega$ 前後のほぼ一定した值を示している。これは雷 揧電流速度に雷撃点の電位上舁は影響を受けないことを意 味している。鉄塔単体の場合にも塔頂インピーダンスは雷 撃モデルによる差はほとんどない。ただし、鉄塔単体のサ ージインピーダンスは上空からケーブルで電流を印加した 場合 ${ }^{(8)}$ よりも約 $10 \Omega$ 低い值になっている。この原因は印 加電流の一部がケーブルシースに流れたためと考えられ、 地上に電源を置いた図 1 の測定法の欠点である。しかし、 測定条件は各雷撃モデルで同一であるから、全笪流が鉄塔 に流れる場合とサージインピーダンスの大小関係は相対的 に変化ないものと考えられる。

図 7 より架空地線の有無によって鉄塔サージインピーダ ンスに差が生じることがかかる。その差は雷撃モデルに依 らずほぼ一定である。また、鉄塔の電位分布割合は架架地 線の有無による影響をうけていない。

今回の雷撃電流路モデルの䐅延構造は鉄塔の電位分布に 影響を与える結果となった。直線導体モテルの電位分布は 下相よりも中相が下回る特徴を示し、折り返し巻線モテル も直線導体モデル比較的似かよった電位分布を示してい る。一方、コイル巻線モテルでは中相は下相より高い電位 分布となる。この原因としては、雷撃電流速度の差と卷線 構造が考えられるが直線導体モテルと折返し巻線モデと の間に差がほとんどないことから前者よりは後者の可能性 が考えられる。すなわち軸方向の磁束は折返し巻線よりは コイル巻線で大きくなることである。

表 1 では雷撃電流伝搬速度の低下にとむなって架空地線 のサージインピーダンスは上昇する結果となっている。架 空地線は水平に墅架しているので、水平 2 条一括線路の特 性インピーダンスの式(16)

$Z=\sqrt{\frac{L}{C}}=30 \sqrt{\log \left(\frac{4 h^{2}}{a D}\right) \cdot\left(\frac{3}{4}+\log \left(\frac{4 h^{2}}{a D}\right)\right.}$

ただし、 $\mathrm{h}$ : 地上高 $\mathrm{a}$ : 架空地線半径 $\mathrm{D}$ : 架空地線蘭距離

において $\mathrm{h}=1.8 \mathrm{~m} 、 \mathrm{a}=3 \mathrm{~mm} 、 \mathrm{D}=44 \mathrm{~cm}$ とすれば特性イン
ピーダンスとして 286V/A が得られ、1 条あたりでは 572 V/A となる。この值は表 1 において直線導体モテルと折返 し巻線モテルの 2 条の平均值に近い。(4) 式は十分時間が 経過して電磁波が TEM 波で近似される場合のサージイン ピーダンスであり、サージの初期部では TEM 波を仮定し た值より低いサージインピーダンスになることが鉄塔の場 合に知られている(2)。近傍側と遠方側でサージインピー ダンスに差があることは测定時間内で未だ TEM 波になっ ていないことを示しているが、コイル巻線モテルではほと んど差がないのにもかかわらず (4) 式より大きな值になっ ている。この場合もコイル巻線は他のモテルと特性が異な っている。

架空地線を架線した場合、各サージインピーダンスが鉄 塔単体時よりも增加している。この原因として 2 つ考えら れる。第 1 は測定上の䜋差であり、特に鉄塔電流は雷撃電 流と架空地線電流の和の差から求めるため俱差が入り易い。 测定では細心の注意を払ったが読取り俱差等で士5V/Aの 誤差は避けられなかった。しかし、誤差だけではインピー ダンスの增加を説明できない。

第 2 として、架空地線と鉄塔間の相互サージインピーダ ンスが考えられる。表 2 は今回測定した各雷撃モデルで鉄 塔サージインピーダンスを求めた時刻における電力線電 王と鉄塔電流の比をまとめたものである。架架地線を切り 雒した鉄塔単体の電力線電圧は鉄塔と大地に水平な線路の 相互サージインピーダンスであるから架空地線と鉄塔間に も同様の相互サージインピータンンスが考えられる。表 1 で は架㘹地線が接続された鉄塔のサージインピーダンスが単 体時よりも䄪 $30 \Omega$ 增加しているが、表2の鉄塔単体の電力 線電圧から、この增加は架空地線亡鉄塔間の相互サージイ ンピーダンスによる可能性が高い。しかし、結論を得るに は円柱モデルなど鉄塔モデルを簡単にして精度の高い測定 や数値電磁界解析などの理論解析が必要である。

\section{3. 相互サージインピーダンスと結合率}

架空地線によって鉄塔単体時よりサージインピーダンス が変化することから、相互誘導が考えられる。そこで鉄塔 単体と架烲地線・電力線がある場合の测定結果から架空地 線と電力線間の結合を考えてみる。

模擬電力線を有する鉄塔縮小モデルの測定から電力線の 架空地線電流や鉄塔電流による相互誘導 (12)を考えるため に図 8 の等価回路を考える。

表 2 各相電力線電压

Table 2. Power-line voltages of each model

\begin{tabular}{|c|c|c|c|c|c|c|c|}
\hline \multirow{2}{*}{\multicolumn{2}{|c|}{ 雷撃電流路モテル }} & \multicolumn{2}{|c|}{ 直線導体モテル } & \multicolumn{2}{|c|}{ 折返し巻線モデル } & \multicolumn{2}{|c|}{ コイル巻線モデル } \\
\hline & & & 鉄塔単体 & & 鉄塔單体 & & 鉄塔単体 \\
\hline \multirow{3}{*}{$\begin{array}{c}\text { 電力線電圧 } \\
(V / A)\end{array}$} & 上相 & 80 & 20 & 78 & 18 & 100 & 28 \\
\hline & 中相 & 67 & 21 & 59 & 20 & 82 & 31 \\
\hline & 下相 & 76 & 33 & 64 & 25 & 96 & 44 \\
\hline
\end{tabular}




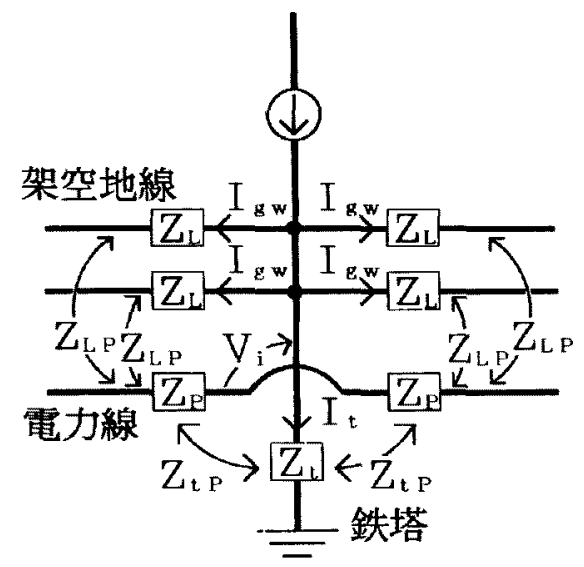

図 8 電力線の相互誘導等価回路

Fig.8. Equivalent circuit to explain mutual induction of power-line

電力線之鉄塔間の電圧は架空地線電流と鉄塔電流、電力 線電流の誘導によって生じるが電力線電流は他の電流に比 して十分小さいと仮定すれば次式が得られる。ただし、各 架空地線と電力線間は同じ相互サージインピーダンスをと るものとする。

$$
4 Z_{L P i} I_{g w}+Z_{t p} I_{t}=V_{i}
$$

$$
\text { ここで } I_{\mathrm{gw}} \text { : 架劦地線電流、 }
$$

I 1 : 鉄塔電流、

$\mathrm{Z}_{\mathrm{LP} \mathrm{i}}$ : 架空地線と各電力線間の相互サージインピー ダンス、 $Z_{1 P}$ : 鉄塔と電力線間の相互サージインピー ダンス、 $V_{i}$ : 各電力線と鉄塔間の電圧

一方、鉄塔単体時の電力線電圧 $\mathrm{V}$ 、は鉄塔電流分にのみ 依存するため次式を満たす。

$$
Z_{t p} I_{t}=V_{i}
$$

ここで架空地線一本当りの電流 $\mathrm{I}_{\mathrm{g}}$ と鉄塔電流 $\mathrm{I}$ の比 が求まれば、表 2 と (5)・(6) 式より各相の架空地線・電力 線間相互サージインピーダンスが求まる。架空地線電流は 印加点近傍側と遠方側とで電流値に差があるが全架空地楾 電流の $1 / 4$ を架空地線一本当りの電流 I $\mathrm{g}$ 涣算する。今 回測定した各雷慗モデルの電流分流比は $\mathrm{Igw}$ 的 1 とすると I、は直線導体、折返し卷線、コイル巻線それぞれ 2.67、 2.76、3.01 倍であった。

各相の架空地線・電力線間相互サージインピーダンスを 表 3 に示す。電力線電圧を使用してインピーダンスを求め ているので電力線電圧分布と同様にコイル卷線モテルの相 互サージインピーダンスは直線導体モデルよりも的 20V/A 高くなっている。この原因としては雷撃モデルの巻線構造 の可能性が考えられる。

結合率は架空地線のサージインピーダンスに対する相導 体の相互サージインピーダンスの割合で求められる。架空 地線のサージインピーダンスとして遠方側と近傍側の値の 平均を使用して各雷揧モテルにおける結合率を表4に示す。 一般的な架空地線 2 条、電力線 6 条の送電線鉄塔の実鉄
表 3 架空地線・電力線間相互サージインピーダンス

\begin{tabular}{|c|c|c|c|c|}
\hline \multicolumn{2}{|c|}{ 雷軗電流路モデル } & 直線導体 & 折返し巻線 & コイル巻線 \\
\hline 相互サージ & 上相 & 40 & 41 & 54 \\
\hline 化 ${ }^{\circ}-3^{*}$ 次 & 中相 & 31 & 27 & 38 \\
\hline$(V / A)$ & 下相 & 29 & 27 & 39 \\
\hline
\end{tabular}

Table 3. Mutual surge impedance between overhead ground wire and power-line

表 4 電力線の架空地線から誘導される結合率

Table 4. Coupling coefficient between overhead ground wire and power-line

\begin{tabular}{c|c|c|c|c}
\hline \multicolumn{2}{c|}{ 雷軗電流路モテル } & 直線導体 & 折返し巻線 & コイル巻線 \\
\hline \multirow{4}{*}{ 結合率 } & 上相 & 0.070 & 0.072 & 0.087 \\
\cline { 2 - 5 } & 中相 & 0.055 & 0.047 & 0.061 \\
\cline { 2 - 5 } & 下相 & 0.051 & 0.047 & 0.063 \\
\hline
\end{tabular}

塔における結合率は上相で $0.32 \sim 0.30$ 、中相で $0.25 \sim$ 0.23、下相で $0.20 \sim 0.18$ とされる ${ }^{(13)}$ 。この鉄塔縮小モ テルでは結合率は実鉄塔の約 $1 / 4$ を示す結果となった。

このような結果は数值電磁界解析を使用した場合 ${ }^{(14)} \mathrm{K}$ も見られており今後さらに検討が必要である。

\section{4. まとめ}

実際の雷撃電流速度を模擬するために電流伝搬速度が光 速の $51 \%$ および29\%の雷撃路モテルを使用して縮小鉄塔 のサージ特性を調べた。鉄塔のサージインピーダンスは光 速の場合とほぼ同じ值となり雷撃電流速度の低下による鉄 塔電位への影響は少ない結果が得られた。したがって、サ ージ解析に使用する鉄塔サージインピーダンスは、従来の 直線導体モデルを使用した雷媻を光速伝搬速度と仮定した 測定や解析において十分評価することが可能である。

また、架線時には、鉄塔书よび架空地線ともに、単体時 よりもインピーダンスの增加が観測された。さらに架空地 線・電力線間結合率を求めたところ、従来より小さな值に なった。これらの現象は鉄塔往復伝搬時間前後のサージ初 期部に特有の現象之考えら机るが、さらに数值電磁界解析 や電磁界理論等による検討が必要である。

(平成 6 年 4 月 4 日受付)

\section{文献}

（1）原 他：「鉄塔伝送線路モテルの実規模鉄塔への適用」電気学 会 放電・高電圧合同研究会, HV-92-94, (1992)

(2) 原 他：「 $24 \mathrm{~m}$ 模授鉄塔のサージ特性測定実験」電気学会 放 電・高電代合同研究会，ED-93-139，HV-93-47， (1993)

（3）原 他：「主材・斜材・アームの三要素よりなる鉄塔多段伝送 線路モテル」笔気学会 放電・高電圧合同研

究会, ED-93-140, HV-93-48, (1993)

（4）井上他：「防雷線による鉄塔逆フラッシオーバの抑制」電気 
学会 全国大会, NO.1281、(1993)

(5) 加藤 他：「送電線鉄塔縮小モテルのサージ特性」電気学会 電力・エネルギー部門大会, No.264, (1992)

（6）加藤 他：「樎小鉄塔モテルのサージ特性（架空地線がある場 合）」電気学会 全国大会, (1992)

(7) 加藤 他：「送電線鉄塔縮小モテルのサージ特性一雷擊路を考 虑した場合一」電気学会 故電・高電压合同研究会, ED-93-141, HV-93-49, (1993)

（8）小島 他：「㷌還雷撃電流による誘導電圧を考虑した逆フラッ シオーバの評価」電気学会論文誌 B，Vol.113， No.11， (1993)

（9）加藤 他：「鉄塔サージインピーダンスの印加電流角度依存特 性の実測」電気学会 全国大会, No.1287, (1991)

(10) 松原 他：「鉄塔サージ応答特性に対する印加電流平愲用抵 抗の影響」電気学会 電力・エネルギー部門大会, No.409, (1993)

（11）望月 他：「鉄塔サージ測定における測定楾配置の影響の検

討」電気学会 全国大会, No.1395, (1993)

(12) Working Group 33.01 : " GUIDE TO PROCEDURES FOR ESTIMATING THE LIGHTNING PERFORMANCE OF TRANSMISSION LINES " CIGRE Paper 33-01 (1991)

(13) 関根 他：「電気・電子工学大百科事典」株式会社 電気書院, (1983)

(14) 加藤、望月 他：「数值電磁界解析による送電線路サージ解 析 (鉄塔雷撃の場合)」電気学会 全国大会, No.1370, (平成 6 年 3 月)

(15) T.Yamada, AMochizuki, J.Sawada, E.Zaima et al.,"Experimental Evaluation of A UHV Tower Model for Lightning Surge Analysis", IEEE 94 WM 044-8 PWRD, 1994

(16) 植野、田村：「近代送電工学」電気書院、1969

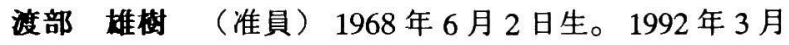

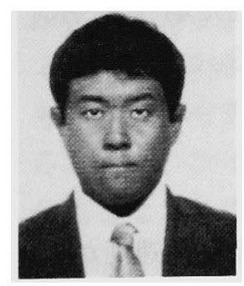
東洋大学工学部電気電子工学科卒業。1 19 94 年 3 月同大学大学院工学研究科電気工 学専攻博士前期課程修了。同年 4 月東京 電力 (株) 入社、現在に至る。
加藤 正平 (正員) 昭和 23 年 9 月 12 生。 46 年 3 月

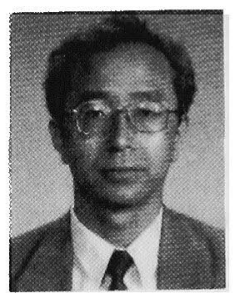
横浜国立大学電気工学科卒業。51 年東京 大学博士課程終了。工学博士。平成 5 年 東洋大学工学部教授。主として、高電圧 測定法、数值電磁界解析、放電現象、サ ージ解析に関する研究に従事。

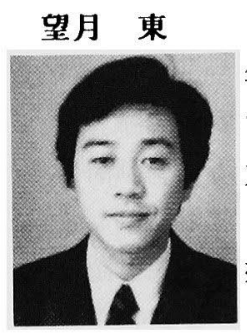

（正員）昭和 34 年 6 月 24 日生。昭和 59 年 3 月東京理科大学大学院理工学研究科 電気工学専攻修士課程終了。59 年東京電 力 (株) 入社。主に、変電技術およびU $\mathrm{H} \mathrm{V}$ 等の絶縁協調の研究に従事。現在、 技術研究所電力研究室主任研究員。

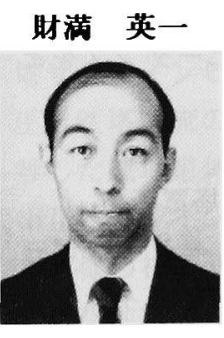

（正員）昭和 24 年 10 月 28 日生。 49 年 3 月東京大学工学部電気工学科卒業。平成 2 年 6 月マサチューセッツ工科大学大学 院修士課程終了。 49 年東京電力 (株) 入 社。主として、変電技術およびUH V 等 の絶縁協調の検討、研究に従事。現在、 技術研究所電力研究室副研究室長。平成 5 年電気学会論文賞受賞。 